\title{
The Determinants of Life Satisfaction in a Low-Income, Poor Community in South Africa
}

\author{
Dr. D.F. Meyer \\ School of Economics, Vaal Triangle Campus of North-West University South Africa \\ Email: Daniel.meyer@nwu.ac.za \\ Dr. S.H. Dunga \\ School of Economics, Vaal Triangle Campus of North-West University South Africa \\ Email: steve.dunga@nwu.ac.za
}

Doi:10.5901/mjss.2014.v5n13p163

\begin{abstract}
The high levels of unemployment in South Africa have resulted in high levels of poverty and inequality. The majority of impoverished people do not have the means to create increased meaning in their lives, leading to low levels of life satisfaction. This paper investigates the determinants of life satisfaction in a poor community. With nearly half of the South African population living in poverty, the question of which variables predict life satisfaction, with specific reference to poor communities, could be asked. The literature indicates that a number of variables can be predictors of life satisfaction in poor areas. The research methodology includes a quantitative household survey in a traditional poor township in southern Gauteng, namely Sicelo. The satisfaction with life scale (SWLS) was used to determine levels of life satisfaction, and a logistic regression analysis was utilised to determine which variables predict life satisfaction. The results of the research confirm that poor communities have relatively low levels of life satisfaction and that specific variables could predict life satisfaction. The logistic regression analysis indicated variables that predict life satisfaction including income levels, employment status, poverty status and government services amongst others. The implication of the research is that policy formulators should also look at the subjective quality of life indicators when compiling and refining policies. This research provides valuable insights into the predictors of life satisfaction of poor people in a traditional South African township.
\end{abstract}

Keywords: life satisfaction, determinants, poverty, binary logistic regression, Sicelo township

\section{Introduction}

Although significant progress has been made regarding service delivery, housing and social welfare aspects in South Africa since the end of apartheid in 1994, poverty, unemployment and inequality are still at high levels (Republic of South Africa, 2011). Large numbers of poor communities are scattered throughout the country twenty years after the first democratic elections. This study seeks to analyse the determinants of life satisfaction of people living in a poor community. In order to understand the concept of life satisfaction, the concepts of subjective well-being, happiness and life satisfaction need to be analysed. These concepts have been used extensively in the past to determine people's level of quality life and living standards. The mentioned concepts have also been utilised by economists to analyse macro and micro economic problems (Kahneman \& Krueger, 2006). The importance of the measurement and value of well-being and associated concepts has been motivated successfully by leaders in the field of research (Diener et al., 2008; Diener \& Suh, 1997). According to Tinkler and Hicks (2011), subjective well-being includes different aspects or components such as happiness, life satisfaction, positive emotions and negative emotions. The use of well-being and life satisfaction measures for policy formulation has increased in recent years. It is argued that such measures should supplement other measures or indicators such as socio-economic ones. Life satisfaction measures factors on a personal level as well as on a community-wide level. Therefore, it provides information regarding individuals, and issues of importance for total communities (Diener et al., 2013).

Diener et al. (2003) differentiate between happiness and life satisfaction by stating that happiness is a more dynamic state, while life satisfaction is a more stable and constant evaluation. This article focuses on the life satisfaction component of well-being as the stable and cognitive components of the concept of well-being.

Poverty is still a global problem and the eradication thereof is one of the main priorities of the Millennium Development Goals (MDG) as declared by the United Nations 2000 (UN, 2003). A total of 2.6 billion people, or approximately 40 percent of the global population, live below the global poverty line of US\$2.00/day, and most of these people live in poverty, lacking essential services and basic needs. In 2005, the wealthiest 20 percent of the world 
population accounted for 76 percent of total private consumption, while the poorest 20 percent of the population accounted for only 1.5 percent of total consumption. The poorest 40 percent of the world population also receives only 5 percent of total income, while the wealthiest 20 percent earn more than 75 percent of total income (Martin \& Hill, 2012; World Bank, 2008).

The European Commission has identified the importance of subjective measurement of quality of life and has set up a sub-commission to investigate alternative measures to gross domestic product (GDP) to measure quality of life and well-being. The use of subjective well-being and life satisfaction surveys were introduced as a result of the commission (Tinkler \& Hicks, 2011). Although it is accepted that objective measures are still of importance, such measures do not take into account human perceptions of life (Layard, 2005). According to the New Economics Foundation (NEF) (2011), the best way to measure an individual's quality of life or life satisfaction is to ask them by means of interviews. Also of importance to note are that subjective well-being and life satisfaction measures correlate well with objective indicators such as income, employment status, age, health and other major life events (Dolan et al., 2008).

Limited research is available regarding life satisfaction in a traditional township in the South African context, and this research attempts to provide some insights in this field of research. The various determinants of life satisfaction in the Sicelo township are tested by means of a logistic regression method.

\section{Conceptual Background}

Sen (1999) states that human well-being means being healthy, well nourished, well clothed, literate, long-lived, to take part in community life, being mobile, and having freedom of choice (Sen, 1999; Todaro \& Smith, 2011). These aspects relate to the basic needs approach, which indicates a close relationship with well-being and life satisfaction. Diener et al. (2003) defines subjective well-being as, "a person's cognitive and affective evaluations of his or her life. Subjective wellbeing is a broad concept that includes experiencing high levels of pleasant emotions and moods, low levels of negative emotions and moods, and high life satisfaction".

According to Ryff (1989), much literature has been generated on the definitions of well-being, and in many cases well-being has been equated to life satisfaction. Life satisfaction and happiness could be seen as indicators of subjective well-being (Rothmann, 2013). Specific major events in an individual's life such as unemployment leading to poverty, disability, and death of a close family member, will possibly have a long-term impact on life satisfaction (Pavot \& Diener, 2008). Lucas et al. (1996) define life satisfaction as, "a global evaluation of a person of his or her life as a whole". Aridas and Pasquali (2012) define life satisfaction as a measure of how people evaluate the entirety of their life and not simply their feelings at the time of the survey. By comparison, Vitterso et al. (2009) define life satisfaction as "a result of their comparisons of the sum of good moments with the sum of bad moments in their lives". To summarise, the main components of life satisfaction include the evaluation of an individual's total life experiences, positive or negative, and making a subjective assessment of the overall balance sheet of life experiences to date.

Keng et al. (2000) state that life satisfaction is a concept that comes from within. An individual will base his or her level of life satisfaction on personal values of importance. Personal value systems differ from person to person. For some people, family or social relations are important, while material items and money satisfy other people. Research has shown that materialistic individuals reported a lower level of life satisfaction if compared to non-materialistic individuals. People with high value for family, social relations and religion reported higher levels of life satisfaction.

According to Rothmann (2013), when individuals assess their quality of life regarding life satisfaction, they weigh the good against the bad, and the results is a general global evaluation of overall satisfaction. Aspects such as social relations, fulfilling and meaningful roles at work and home, a meaningful religious and spiritual life, ongoing learning and growth, and recreation and leisure time, also influence an individual's evaluation of life satisfaction. An individual with a fulfilling job and good working conditions that stimulate personal growth will have a higher life satisfaction level if compared to somebody who is unemployed for example (Pavot \& Diener, 2008). Clark et al. (2013), in a survey in Germany, found that life satisfaction levels decrease with the incidence and intensity of poverty.

Poverty leaves long-term scars on people. Even when moving out of poverty they still have lower life satisfaction levels if compared to people who have never experienced poverty. This aspect of poverty and life satisfaction is supported by Cappellari and Jenkins (2004) stating that "the experience of poverty itself might induce a loss of motivation, lowering the chances that individuals with given attributes escape poverty in future". Clark et al. (2013) continue with more findings on poverty and life satisfaction. Poverty is correlated significantly negatively with life satisfaction. BiswasDiener and Diener (2001) found the same result in poor areas of Calcutta, India. Clark et al. (2013) state that higher income levels allow for higher levels of life satisfaction, but additional income only leads to an increase of life satisfaction at a decreasing or diminishing rate. Earlier research by Diener et al. (1993) and Veenhoven (1991) confirm this finding.

Individuals living in wealthier countries, on average have higher life satisfaction than individuals residing in very 
poor countries (OECD, 2009). It also appears that an increase in income makes a larger difference to life satisfaction within poorer societies than in wealthy ones (Diener \& Biswas-Diener, 2002), although the impact is smaller than people might think (Aknin \& Norton, 2009). If low-income communities are compared to medium- and high-income communities, a marked difference in life satisfaction exists. Low-income communities focus on sheer survival strategies, and life satisfaction is linked closely to availability of basic needs. Communities with higher incomes attach more importance to freedom of choice regarding life satisfaction (Diener et al., 2013).

As early as 1776, Adam Smith stated, "No society can surely be flourishing and happy, if the greater part of the population is poor and miserable" (Smith, 1776). This historical statement is still true today in modern, post-apartheid South Africa. The concept of poverty and the measurement thereof are important concepts. Many different definitions of poverty exist; a distinction is made between absolute, relative and subjective poverty. In this study, absolute poverty is used as the method of measurement. Absolute poverty is defined as an individual or household with an income lower than the income level objectively defined. This is the minimum income required to satisfy basic needs (Bayram et al., 2012). The World Bank (2001) defines poverty as a situation where an individual lacks command over commodities deemed essential to realise a reasonable standard of living. When working with poverty, it is necessary to set a poverty line in order to identify people as poor individuals with incomes below the calculated threshold or poverty line. Various methods exist to set the poverty line such as the US\$1.25 or US\$2 per day method, or as used in the European Union approach, at 60 percent of the national median equivalent income (Clark et al., 2013:4).

Guardiola and Garcia-Munoz (2009) state that the basic needs approach to fighting poverty has, since the declaration of the MDG in 2001, taken prominence again. Research has shown a positive relationship exists between provision of basic needs, lessening of poverty levels and life satisfaction. Although various measures and scales exist for life satisfaction, the satisfaction with life scale (SWLS) is used widely, and is also used in this study (Diener et al., 1985).

Many researchers have investigated and identified predictors and determinants of life satisfaction. Veenhoven (1996) states that such determinants could be classified as internal conditions including self esteem or outlook on life, and external conditions such as employment or housing. External conditions are the focus of this study and Veenhoven (1996) found that housing type, income, education, employment status, age, gender, and physical health are factors that could determine the level of life satisfaction. Dolan and Metcalf (2011), Clark et al. (2013) and Bayram et al. (2012) have also listed some of the determinants of life satisfaction. Such determinants include income, employment status, level of education, health status, age, family size, social security, gender, socio-economic conditions, religion, and level of service delivery. Kingdon and Knight (2006) also confirmed the above listed determinants in research.

According to Muzindutsi and Sekhampu (2014), in a poor South African community where life satisfaction was analysed, the following findings were listed: household size had a negative correlation with life satisfaction, while employment (Hutchinson et al., 2004), age, education (Le Roux \& Kagee, 2008), income (Kingdon \& Knight, 2006), gender and marital status had positive correlations with life satisfaction. An interesting finding by Graham and Felton (2006) indicated that rural communities are more satisfied with life than more urbanised communities; Youmans (1971) supports this finding. Lastly, Bjornskov et al. (2006) found that politics and government service delivery could have a substantial impact on quality of life of individuals and total communities. Table 1 is a summary of the determinants of life satisfaction as were collected during the literature review process. It should be noted that generalisations were made in the table, and the determinants of life satisfaction could be affected by individual and environmental conditions, leading to different outcomes when analysed.

Table 1: Summary of some of the determinants of life satisfaction

\begin{tabular}{|l|l|}
\hline Determinants of life satisfaction & \multicolumn{1}{|c|}{ Generalised correlation with life satisfaction } \\
\hline Education & Higher levels of education lead to higher levels of life satisfaction. \\
\hline Marital status & Married people have a higher life satisfaction than single people. \\
\hline Health status & Good health relates to higher levels of life satisfaction. \\
\hline Income level & Higher levels of income lead to higher levels of life satisfaction. \\
\hline Employment & Employed people have higher levels of life satisfaction. \\
\hline Rural areas & People in rural areas have a higher level of life satisfaction. \\
\hline Household size & Larger households have lower levels of life satisfaction. \\
\hline Religion & Religious people have higher levels of life satisfaction. \\
\hline Age & Older people have higher levels of life satisfaction. \\
\hline Government services & Improved service provision and delivery leads to improved life satisfaction. \\
\hline Poverty status & Higher levels of poverty relate to lowers levels of life satisfaction. \\
\hline Gender & Women have lower levels of life satisfaction than men do. \\
\hline
\end{tabular}

Source: Own compilation from the literature review 


\section{Methodology}

\subsection{The study area}

The geographical focus area for the study is the Sicelo township, which is a poor residential community traditionally, within a South African municipal setting located in southern Gauteng. The area is located approximately $60 \mathrm{~km}$ south of the Johannesburg central business district (CBD) and forms part of the Midvaal municipal area. The township is located adjacent and to the west of the R59 freeway, which links Johannesburg with the Vaal Triangle region. The township consists of approximately 4000 housing units, of which close to 50 percent are informal units. It has a population of approximately 15200 people and limited community facilities, with only a sports field, early learning centre, clinic, primary school, and limited retail facilities.

\subsection{Research design}

This study followed an empirical and quantitative research approach. Primary data were collected by means of a questionnaire during a random socio-economic household survey in the study area during January 2014.

\subsection{Participants}

A sample of 400 households in the study area was selected randomly relating to a 10 percent sample size. Trained fieldworkers conducted the survey and administered a survey questionnaire to all participants. All interviews were conducted with the head of the household. A cover letter explaining the purpose of the study, emphasising the aim and confidentiality of the research project, accompanied the questionnaire. Participation in the project was voluntary and respondents had the option to withdraw at any stage.

\subsection{Measuring instruments}

The questionnaire contained many aspects that will be used in future research. The measuring instrument that was used as part of the questionnaire relating to this article is the SWLS (Diener et al., 1985). The scale was used to measure the cognitive component of well-being.

\subsection{Ethical considerations}

Prior to the administration of the questionnaire, relevant ward councillors were approached with a request to conduct the study in the area. After permission was granted, potential participants were approached and informed consent was obtained from participants. Participants were assured of confidentiality and anonymity. The participation was voluntary.

\section{Results of Statistical Analysis}

\subsection{Poverty and life satisfaction}

The survey data was captured and analysed using the Statistical Package for the Social Sciences (SPSS) software. Income levels in Sicelo are low at approximately R2 400 (\$226) per month per household. Life satisfaction is also relatively low with more than 76 percent of households indicating dissatisfaction with life. The fact that a large proportion of households feel dissatisfied with their lives is expected in a poor community such as Sicelo with its high levels of unemployment. Life satisfaction is a subjective concept and there are a number of variables to determine a person's perception of how he/she feels about his/her life. Often, income is considered an important factor, allowing access to resources and how a person may satisfy his or her needs.

In this study, a number of variables are considered as determinants of life satisfaction at the household level, as reported by the head of the household. These include income, household size, education level of the head of household, employment status, poverty status as measured by the income poverty line of R660 (\$62) per person per month, and also the age of the head of household. These factors were used as the independent variables, while life satisfaction was used as the dependent variable. Table 2 presents the descriptive statistics of life satisfaction in the study area. Levels of dissatisfaction with life are high in the community at 76.1 percent, while only 23.9 percent indicated satisfaction with life. 
Table 2: Descriptive statistics of life satisfaction in study area

\begin{tabular}{|l|c|c|}
\hline \multicolumn{1}{|c|}{ Responses regarding life satisfaction } & Number of households (Frequency) & Percentages (\%) \\
\hline Not satisfied with life & 306 & 76.1 \\
\hline Satisfied with their life & 96 & 23.9 \\
\hline \multicolumn{1}{|c|}{ Total } & 402 & 100.0 \\
\hline
\end{tabular}

The poverty status was calculated using the international US\$2 per day, per person poverty line. To come up with a poverty line for individuals in the household, the $\$ 2$ was multiplied by 30 (average number of days in a month) and then by the exchange rate of R11.00 to $\$ 1$. The monthly poverty line for an individual was calculated and set at R660 (\$62) per month. Of all the households, 56.5 percent are classified as poor and below the poverty line, while 43.5 percent of households are classified as poor but above the poverty line. This is an indication that the majority of the people in the sample were poor. Even the households above the poverty line are just marginally above the poverty line. The poverty status of households was calculated using income per capita, which is a reflection of the importance of income as one of the main determinants considered in this paper. Table 3 presents a summary of the household poverty status in the study area.

Table 3: Descriptive statistics of poverty status in the study area

\begin{tabular}{|c|c|c|}
\hline $\begin{array}{c}\text { Poverty status of households in the study area } \\
\text { (Variable) }\end{array}$ & $\begin{array}{c}\text { Number of households } \\
\text { (Frequency) }\end{array}$ & Percentage (\%) \\
\hline Households above the poverty line & 175 & 43.5 \\
\hline Households below the poverty line & 227 & 56.5 \\
\hline Total & 402 & 100 \\
\hline
\end{tabular}

Another determinant of life satisfaction considered in the literature was the employment status of the head of the household. Table 4 presents the frequencies as found in the survey. The expectation is that people without a job are likely to be dissatisfied with life as joblessness may imply, in most cases, absence of income, and hence difficulties to maintain and provide in the needs of the household. Unemployment also affects the self esteem of individuals. More than 40 percent of the heads of households were not economically active, while only 12.2 percent indicated unemployment. In reality, it could be noted that only 27 percent of heads the heads of households are formally employed in the study area.

Table 4: Descriptive statistics of employment status in the study area

\begin{tabular}{|r|l|c|c|c|}
\hline \multicolumn{2}{|c|}{ Employment status of head of household } & Frequency & Percentage (\%) & Cumulative Percent (\%) \\
\hline \multirow{4}{*}{ Valid } & Formal employment & 109 & 27.1 & 27.1 \\
\cline { 2 - 5 } & Informal employment & 79 & 19.7 & 46.8 \\
\cline { 2 - 5 } & Unemployed & 49 & 12.2 & 59.0 \\
\cline { 2 - 5 } & Not economically active & 165 & 41.0 & 100.0 \\
\cline { 2 - 5 } & Total & 402 & 100.0 & \\
\hline
\end{tabular}

A common feature in most townships in South Africa is the low-income levels of households. The poor find it very hard to find decent accommodation and 2.3 million households in South Africa live in informal housing (StatsSA, 2011). In this study, the type of housing (formal or informal) the household was residing in was also used as a determinant of life satisfaction. Table 5 presents the results of the type of housing per household. Although some formal housing has been provided in the community, only 40 percent of households have received subsidised housing to date. It has been confirmed that more houses will be delivered in the near future in the area.

Table 5: Descriptive statistics of type of housing in the study area

\begin{tabular}{|c|c|c|}
\hline \multicolumn{1}{|c|}{ Variable } & Frequency & Percentage (\%) \\
\hline Informal & 240 & 59.7 \\
\hline formal house & 162 & 40.3 \\
\hline Total & 402 & 100.0 \\
\hline
\end{tabular}




\subsection{Logistical regression on the determinants of life satisfaction}

Using life satisfaction measured as the dependent binary variable, and the variables explained above as the independent variables, equation (1) below is estimated as follows:

$$
L S_{1 o r 0}=\phi_{0}+\phi_{1} X_{1}+\cdots+\sum_{n}^{i} \phi_{i} X_{i}+\varepsilon
$$

Where LS is the life satisfaction binary variable entered as one if satisfied with life and zero for being dissatisfied with life. The intercept is represented by $\phi_{0}$ and $\phi_{1}$ to $\phi_{i}$ as the parameters that estimate the change in probability of being in one category as a result of the change in the independent variable concerned. However, being a logistic regression, the $\phi_{1}$ will not give the change but the odd ratio which is the exponential of the $\phi$ presented as $e^{\phi}$.

Therefore, the independent variable is represented in equation (1) as ${ }^{X_{1}}$ to $X_{n}$. These are clearly defined in Table 6, which contains the logistic regression results.

Table 6: Results of the logistic regression with life satisfaction as a dependent variable

\begin{tabular}{|c|c|c|c|c|c|c|c|c|}
\hline \multirow{2}{*}{ Variables } & \multirow{2}{*}{ B } & \multirow{2}{*}{ S.E. } & \multirow{2}{*}{ Wald } & \multirow{2}{*}{ Df } & \multirow{2}{*}{ Sig. } & \multirow{2}{*}{$\operatorname{Exp}(B)$} & \multicolumn{2}{|c|}{$95 \%$ C.I. for EXP(B) } \\
\hline & & & & & & & Lower & Upper \\
\hline Household size & .068 & .089 & .589 & 1 & .443 & 1.071 & .899 & 1.275 \\
\hline $\mathrm{HH}$ total income & .000 & .000 & 7.896 & 1 & $.005^{\star \star \star}$ & 1.000 & .999 & 1.000 \\
\hline Poverty status & -1.724 & .463 & 13.867 & 1 & $.000^{\star \star *}$ & .178 & .072 & .442 \\
\hline Formal employment & & & 6.263 & 3 & $.099 *$ & & & \\
\hline Informal employment & -.062 & .438 & .020 & 1 & .887 & .940 & .399 & 2.216 \\
\hline Unemployed & .424 & .518 & .671 & 1 & .413 & 1.528 & .554 & 4.217 \\
\hline Not economically active & .950 & .430 & 4.882 & 1 & $.027^{\star *}$ & 2.585 & 1.113 & 6.001 \\
\hline Qualification & .044 & .044 & .997 & 1 & .318 & 1.045 & .959 & 1.139 \\
\hline Housing subsidy & -.382 & .431 & .788 & 1 & .375 & .682 & .293 & 1.587 \\
\hline Age & .004 & .008 & .243 & 1 & .622 & 1.004 & .988 & 1.020 \\
\hline House type & .559 & .470 & 1.415 & 1 & $.099^{*}$ & 1.750 & .696 & 4.399 \\
\hline Government service & .250 & .132 & 3.599 & 1 & $.058^{*}$ & 1.284 & .992 & 1.663 \\
\hline Constant & -1.400 & .986 & 2.017 & 1 & .156 & .246 & & \\
\hline
\end{tabular}

*** Significant at 1 percent, ** significant at 5 percent and * significant at 10 percent

Source: Estimated using survey data (2014)

\section{Discussion and Findings}

The results of the logistic regression indicate that poverty status is a significant determinant of life satisfaction with a $p$ value of 0.000 and a Wald test statistic of 13.8, thus significant at 1 percent significance level. The beta value also had a negative sign, as expected. Since poverty status was defined as one for below the poverty line and zero for above the poverty line, the negative sign implies that those households below the poverty line have a higher probability of reporting dissatisfaction with life. The odds ratio, which is reported as the exponential of $B$ or $\operatorname{Exp}(B)$, presents the marginal change in the probability of falling in the category of those that reported dissatisfaction with their lives. This result is similar to that found by Biswas-Diener and Diener (2001). This result is also highly related to the variable on income. Income is found to be a significant factor with a p-value of 0.005 and a Wald test of 7.9, thus it is also significant at a 1 percent significance level. The sign of the beta is positive, indicating that an increase in income increases the probability of life satisfaction. The result on income corresponds with a study by Kapteyn et al. (2009) who argued that there is always an associated increase in life satisfaction as a result of increases in income. A study by Helliwell and Wang (2008) found that income is one of the important factors as far as life satisfaction is concerned.

Employment status, which was entered for categories, namely formally employed, informally employed, unemployed, and not economically active. It was found to be significant in the two categories of formally employed ( $p$ value 0.099 ) and not economically active ( $p$-value 0.027 ). The formally employed were found to have a positive coefficient, which means that being formally employed increased the probability of reporting satisfaction with life. Those in informal employment had a negative coefficient, meaning that being in that category increased the probability of reporting dissatisfaction with life. An interesting result is on those who are not economically active. The results show that there is a positive coefficient, which may imply that those not economically active have a higher probability of being in the category 
reporting life satisfaction. The logical explanation to this result could be that most people that are recorded as not economically active are mostly the older people, and the chance of older people being satisfied with their situation is higher compared to younger people who still have life ambitions to be achieved. The age coefficient in the regression, which was also found to be positive, confirmed the argument that the older the person, the higher the probability of being satisfied with their life.

It was also found that housing type and government service delivery have a positive impact on life satisfaction. The results indicate $p$-values of 0.099 and 0.058 respectively for the two determinants. Bjornskov et al. (2006) found a similar result. Their study, however, found that household size, qualifications, housing type and age did not significantly predict life satisfaction in the study area.

The model fitness was also checked by means of the Hosmer and Lameshow test, which has a null hypothesis that states that the model fitness is good. For a good model fit, the null hypothesis of the Hosmer and Lameshow test has to be accepted, and the p-value has to be greater than 0.05 for a 5 percent significance level. The Hosmer and Lameshow test result of the regression is reported in Table 7. The results indicate that the model was a good fit. Other tests that also test the model fitness such as the Cox and Snell R, and the Nagelkerke R, also show that the model was a good fit.

Table 7: The Hosmer and Lameshow test

\begin{tabular}{|c|c|c|c|}
\hline Step & Chi-square & Df & Sig. \\
\hline 1 & 5.747 & 8 & .676 \\
\hline
\end{tabular}

\section{Recommendations}

The use of subjective measures such as life satisfaction plays an important role in the analysis of socio-economic conditions. Results can provide government with indicators that could be used to improve the quality of life of people. Measures of well-being and life satisfaction by means of subjective household or individual surveys need to lead to improved policy formulation. According to Dolan and Metcalf (2011), subjective survey data could be used to monitor progress, to inform policy design, and for policy appraisal. It is of further importance that specific sub-groups be identified for special focus such as the unemployed, or people in poverty in specific geographical areas. Policy formulation should be focused on groups and localities where life satisfaction and quality of life is perceived to be low (Helliwell, 2011).

Quality of life, in a community such as Sicelo with the mono-land use character, is expected to be low. More than 50 percent of residences are informal in nature, and basic services are limited, especially in the informal sections. Limited community facilities exist, which also contributes to the relatively low levels of quality of life and eventual low levels of life satisfaction. The results of the life satisfaction survey need to be converted into policy that could assist in improved quality of life and life satisfaction. Such policy aspects could include the following: Increased social-welfare programmes and spending in the specific area; the introduction of income generating projects such as public works projects and community food gardens; the introduction of job creation projects linked to skills training; accelerated provision of community facilities such as schools, clinics, sports facilities, open space, social facilities and retail; accelerated provision of basic needs and essential services; the introduction of community cohesion projects and family development programmes; improved safety nets and asset development; programmes in financial management and budget education and nutrition; and health care programmes for identified communities.

The study has proven that detailed subjective life satisfaction surveys and data analysis could assist in identifying local problems, as every community is unique and has different challenges with different solutions. Such investigations can lead to improved policy formulation taking into account trends in a specific area. Subjective life satisfaction studies are effective tools in designing development policies. The focus should be on those determinants that can change the life satisfaction of people. Institutional life satisfiers should also be prioritised (Frey \& Stutzer, 2002). Understanding of life satisfaction determinants is important for successful policy formulation.

\section{Conclusions}

A number of determinants exist which could predict the subjective life satisfaction of a specific household or even a total community. In this study, it was found that income, poverty status, employment status, type of housing and levels of government services are predictors of life satisfaction in a poor community. Government, to amend and implement policies, should use the results from studies such as this one. The finding in the study compares well with other similar studies. The results of the research could fill the gap that currently exists regarding information in poor areas and the 
needs of poor communities.

\section{References}

Aknin, L. B., \& Norton, D. (2009). From wealth to well-being? Money matters, but less than people think. Journal of Positive Psychology, 4: 6, 523-527.

Aridas, T., \& Pasquali, V. (2012). The happiest countries in the world. [Online] Available: www.gfmag.com/tools/global-database (February 72014.

Bayram, N., Aytac, S., Aytac, M., Sam, N., \& Bigel, N. (2012). Poverty, social exclusion, and life satisfaction: a study from Turkey. Journal of Poverty, 16, 375-391.

Biswas-Diener, R., \& Diener, E. (2001). Making the best of a bad situation: satisfaction in the slums of Calcutta. Social Indicators Research, 55: 3, 329-352.

Bjornskov, C., Dreher, A., \& Fischer, J. A. V. (2006). Cross-country determinants of life satisfaction: exploring different determinants across groups in society. Political economy and public policy series. London: The Suntory Centre.

Cappellari, L., \& Jenkins, S. P. (2004). Modelling low income transitions. Journal of Applied Econometrics, 19, 593-610.

Clark, A. E., D'Ambrosio, C., \& Ghislandi, S. (2013). Poverty and well-being: panel evidence from Germany. PSE Working Paper. [Online] Available: http://ideas.repec.org/p/inq/inqwps/ecineq2013-291.html (February 3, 2014).

Diener, E. \& Biswas-Diener, R. (2002). Will money increase subjective well-being? Social Indicators Research, 57: 2, 119-169.

Diener, E., Emmons, R. A., Larsen, R. J., \& Griffen, S. (1985). The satisfaction with life scale. Journal of Personality Assessment, 49, 71-75.

Diener, E., Inglehart, R., \& Tay, L. (2013). Theory and validity of life satisfaction scales. Social Indicators Research, 112, 497-527.

Diener, E., Kesebir, P \& Lucas, R. (2008). Benefits of accounts of well-being: for societies and for psychological science. Applied Psychology, 57: 1, 37-53.

Diener, E., Oishi, S., \& Lucas, R. E. (2003). Personality, culture and subjective well-being: emotional and cognitive evaluations of life. Annual Review of Psychology, 54, 403-425.

Diener, E., Sandvik, E., Seidlitz, L., \& Diener, M. (1993). The relationship between income and subjective well-being: Relative or absolute? Social Indicators Research, 28:3, 195-223.

Diener, E \& Suh, E. (1997). Measuring quality of life: economic, social and subjective indicators. Social Indicators Research, 40, 189216.

Dolan, P., \& Metcalf, R. (2011). Comparing measures of subjective well-being and views about the role they should play in policy. [Online] Available: www.ons.gov.uk (February 3, 2014).

Dolan, P., Peasgood, T, \& White, M. P. (2008). Do we really know what makes us happy? A review of the economic literature on factors associated with subjective well-being. Journal of Economic Psychology, 29, 94-122.

Frey, B. S., \& Stutzer, A. (2002). Happiness and economics: how the economy and institutions affect human well-being. Princeton: Princeton University Press.

Graham, C. \& Felton, A. (2006). Inequality and happiness: insights from Latin America. Journal of Economic Inequality, 4: 1, 237-268.

Guardiola, J., \& Garcia-Munoz, T.G. (2009). Subjective well-being and basic needs: evidence from rural Guatemala. The Papers. Department of Economic Theory and History. Granada: University of Granada.

Helliwell, J. F. (2011). How can subjective well-being be improved? [Online] Available: www.csls.ca/events/2011/helliwell.pdf (February $3,2014)$.

Helliwell, J. F., \& Wang, S. (2008). Trust and wellbeing. International Journal of Wellbeing, 1: 1, $42-78$.

Hutchinson, G., Simeon, D., Bain, B., Wyatt, G., Tucker, M. \& Lefranc, E. (2004). Social and health determinants of well being and life satisfaction in Jamaica. International Journal of Social Psychiatry. 50: 1, 43-53.

Kahneman, D., \& Krueger, A. B. (2006). Developments in the measurement of subjective well-being. Journal of Economic Perspectives, 20: $1,3-24$.

Kapteyn, A., Smith, J. P., \& Van Soest, A. (2009). Life satisfaction. IZA discussion paper no 4015. Bonn, Germany.

Keng, A. K., Jung, K., Jiuan, T.S., \& Wirtz, J. (2000). The influence of materialistic inclination on values, life satisfaction and aspirations: an empirical analysis. Springer, 39: 3. 317-333.

Kingdon, G., \& Knight, J. (2006). Subjective well-being poverty versus income poverty and capabilities poverty. The Journal of Development Studies, 42: 7, 1199-1224.

Layard, R. (2005). Happiness: lessons from a new science. London: Penguin.

Le Roux, M., \& Kagee, A. (2008). Subjective well being of primary healthcare patients in the Western Cape, South Africa. South African Family Practice, 50: 3, 68-79.

Lucas, R, Diener, E, \& Suh, E. (1996). Discriminant validity of well-being. Journal of Personality and Social Psychology, 71: 3, 616-628.

Martin, K. D., \& Hill, R. P. (2012). Life satisfaction, self-determination, and consumption adequacy at the bottom of the pyramid. Journal of Consumer Research, 38, 1155-1168.

Muzindutsi, P. F., \& Sekampu, T. J. (2014). Determinants of wellbeing in a South African township. International Journal of Social Sciences and Humanity Studies, 6: 1, 47-57.

New Economics Foundation (NEF). (2011). Measuring our progress. [Online] Available: www.neweconomics.org/publications/measuringour-progress (February 3, 2014). 
OECD see Organisation for Economic Cooperation and Development.

Organisation for Economic Cooperation and Development (OECD). (2009). Society at a glance 2009: OECD social indicators. OECD Publishing. [Online] Available: http://dx.doi.org/10.1787/soc_glance-2008-30-en (February 6, 2014).

Pavot, W., \& Diener, E. (2008). The satisfaction with life scale and the emerging construct of life satisfaction. Journal of Positive Psychology, 3, pp 137-152.

Republic of South Africa. (2011). National Development Plan, 2030. The National Planning Commission. Department of the Presidency. Pretoria: Government Printer.

Rothmann, S. (2013). Measuring happiness: results of a cross-national study. In: M. P. Wissing (Ed.), Well-being research in South Africa. New York: Springer.

Ryff, C. D. (1989). Happiness is everything, or is it? Explorations on the meaning of psychological well-being. Journal of Personality and Social Psychology, 57: 6, 1069-1081.

Sen, A. K. (1999). Development as freedom. New York: University Press.

Smith, A. (1776). The wealth of nations. Random House Publishers.

Statistics South Africa. (2011). Census 2011 municipal fact sheet. Pretoria: Government printer.

Survey data. (2014). Results of a household community survey conducted in Sicelo Township in January 2014, coordinated by DF Meyer. NWU: Vaal campus, Vanderbijlpark.

Tinkler, L., \& Hicks, S. (2011). Measuring subjective well-being. Office of National Statistics. UK Statistics Authority. Newport. South Wales.

Todaro, M. P., \& Smith, S. C. (2011). Economic development. (11th ed.). Essex: Pearson Education Limited.

UN see United Nations

United Nations (UN). (2003). Human development report, 2003 - Millennium development goals: a compact amongst nations to end human poverty. New York: Oxford University Press.

Veenhoven, R. (1991). Is happiness relative? Social Indicators Research, 24, 1-24.

Veenhoven, R. (1996). The study of life satisfaction. In W. E. Saris, R. Veenhoven, A. C. Scherpenzeel, \& B. Bunting (Eds.), A comparative study of satisfaction with life in Europe (pp.11-48). Budapest. Eotvos University Press.

Vitterso, J., Oelmann, H. I., \& Wang, A. L. (2009). Life satisfaction is not a balanced estimator of the good life: evidence from reaction time measures and self-reported emotions. Journal of Happiness Studies, 10: 1, 1-17.

World Bank. (2001). Poverty manual. Washington: World Bank Institute.

World Bank. (2008). Waves of LED. [Online] Available: http://go.worldbank.org (June16, 2011.

Youmans, E. G. (1971). Poverty and life satisfaction: a rural-urban comparison. Lexington: Kentucky University. 